\title{
EFFECT OF WHEAT FLOUR TYPE, FLOUR EXTRACTION RATE AND FLOUR PARTICLE SIZE ON NOODLES QUALITY
}

\author{
*Saad A. Hallabo; *Mahmoud A. A. Bekheet; **Sayed Abdel-Bar Salem and \\ **Hatem S. M. Aly
}

\begin{abstract}
Factors affecting quality of instant fried noodles i.e., flour type, extraction rate of flour and particle size of flour were studied. The results indicated that noodles made from hard Sohag I wheat flour (72\% extraction) showed the highest weight and volume gain, while those made from hard red winter wheat flour (72\% extraction) showed superior color, highest firmness score and lowest cooking loss. Noodles made from Sohag I wheat flour showed the highest degree of overall acceptability followed by those made from hard red winter wheat flour then those made from soft white wheat flour. Concerning the effect of extraction rate, the results indicated that noodles made from Sohag I of $72 \%$ extraction rate showed highest firmness, color and low increase in weight and volume gain in addition to higher scores for all the organoleptic properties compared to those made from wheat flour with $62 \%$ extraction rate from the same variety. Moreover, the results also indicated that noodles made from fraction (2) of Sohag I (72\% extraction) with particle size more than 63 micron and lower than 125 micron showed the highest firmness and the lowest color and cooking properties compared to those made from fraction (1) of the same flour with particle size more than 125 micron and lower than 250 micron. However, no significant difference was found between the noodles made from fractions 1 , 2 and those made from the parent flour for most of the tested sensory properties and overall acceptability.
\end{abstract}

Keywords: Noodles - Macaroni - Wheat - Flour - Extraction rate.

\section{INTRODUCTION}

Pasta products such as macaroni, spaghetti and noodles are very popular in the world and many types are produced throughout many countries. In their simplest form, wheat noodles are a type of pasta prepared from a dough containing flour, water and salt. The standard of identity for noodles in the united states specified that noodles " are usually made from durum wheat flour dough containing eggs". The dried noodles must contain $\geq 87 \%$ solids and $\geq 5.5$ egg solids (Code of Federal Regulation, 1981). Noodles can also be made from bread wheat flour with finer particle sizes similar to semolina (Miskelly, 1993).

Instant noodles are generally refer to the steamed and deep-fat fried products, which are called Ramyon in Korea and Rawen in Japan. Instant noodles in those areas are sold in a bag, cup, or bowl in which a soup base is separately added. However, several factors may be considered in the evaluation of instant noodle quality. These are flour quality, processing conditions, eating quality and keeping quality (Kim, 1996).

Quality of dry noodles can be evaluated by breaking stress and color of uncooked noodles and cutting force and surface firmness of the cooked noodles. The gluten fraction controlled the cutting stress and surface firmness while tailing starch fraction controlled noodle color (Oh et al., 1985a).

This investigation was carried out to study the effect of flour type, extraction rate and particle size on the instant fried noodles quality.

Fayoum J. Agric. Res. \& Dev., Vol.24, No.2, July, 2010 


\section{MATERIALS AND METHODS}

\section{Materials:}

- Wheat flours of $72 \%$ and $62 \%$ extraction were prepared by milling Egyptian wheat varieties (Sohag 1 and Giza 164) which were obtained from the Agricultural Research Center, Ministry of Agriculture, Giza, Egypt.

- Flours of American wheat varieties (Hard Red Winter and Soft White) with 72\% extraction were obtained from North Cairo Milling Company,Giza, A.R.E.

- Fresh palm oil for frying process was obtained from Misr Food Ind. Company, Giza, A. R. E. with initial peroxide value (0.210 mequ. Peroxide / kg oil).

\section{Methods:}

\section{2:1. Milling process of Egyptian wheat varieties:}

Hard wheat variety (Sohag 1) and soft wheat (Giza 164) were tempered to 15 and $14 \%$ moisture, respectively for 24 hours, then milled using Brabender mill and sieved to obtain flours with extraction rates of either $72 \%$ or $62 \%$ for each variety. Wheat flour of $72 \%$ extraction that was obtained from Sohag 1 variety was fractionated into several fractions by sieving. Fractions less than $0.063 \mathrm{~mm}$ or more than $0.250 \mathrm{~mm}$ were rejected since both sizes are not suitable for noodles preparation. Fractoins between $0.063 \mathrm{~mm}$ and $0.250 \mathrm{~mm}$ were devided to two fractions. Fraction (1) contained particles with size more than $0.125 \mathrm{~mm}$ and less than $0.250 \mathrm{~mm}$ (coarse fraction) and fraction (2) contained particles with size more than $0.063 \mathrm{~mm}$ and less than $0.125 \mathrm{~mm}$ ( fine fraction ).

\section{2:2. Preparation of noodles samples:}

Noodles were processed in the Food Tech. Lab, N. R. C. Cairo, Egypt, according to the procedures described by Fen and Seib (1994) as follows: wheat flour (500 grams) and salt (1.7\%) were placed in the bowl of the machine (Matic 1000 Simac Machine Corporation, Millano, Italy). Optimum level of water (as determined by handling method) was added slowly over a period of 3 minutes. The optimum level of water must be sufficient to hydrate all flour particles, as evidenced by the absence of white specks in the extruded strands of noodles. Extruded strands were cut to lengths of $50-60 \mathrm{~cm}$ and thickness was $1.3 \mathrm{~mm}$.

The stands noodles obtained were steamed and fried according to the method of Rho et al. (1986) as follows: the strands noodles $(100 \mathrm{gm})$ were placed randomly in a wire basket $(115 \times 115 \times 90 \mathrm{~mm})$ fitted with a lid and steamed for 3 minutes on each side in an aluminum steamer. Immediately after steaming, the baskets were immersed in $4 \mathrm{~kg}$ palm oil for 45 seconds at $150^{\circ} \mathrm{C}$ in a fryer. Each batch of oil $(4 \mathrm{~kg})$ was discarded after one single frying operation. The fried noodles were removed from the frying and allowed to drain the excess oil for 20 seconds. Finally, noodles were packaged in the packaging material (polyethylene ).

\section{2:3- Chemical analysis:}

Moisture, protein, lipids, ash and fiber contents were determined according to the methods described in A.O.A.C. (2005). Total carbohydrates (NFE ) content was determined by difference.

\section{2:4- Cooking quality of instant fried noodles:}

Cooking quality of instant fried noodles, i.e., weight gain, volume gain and cooking loss were determined according to the methods of Gu - Sik and Sung - Kon (1991).

2:5- Noodles firmness: Firmness of noodles samples were measured as described by Walash and Gilles (1971).

2:6- Noodles color: The color of noodles was determined according to the method of Habib and Brown (1956).

Fayoum J. Agric. Res. \& Dev., Vol.24, No.2, July, 2010 
2:7- Pigment contents: Pigment contents of different wheat flours under study were determined according to the method of A.O.A.C. (2005).

2:8- Sensory evaluation of cooked noodles was carried out according to the method of Galvez and Resurreccion (1990).

2:9- Statistical analysis of the results of the sensory evaluation was carried out according to the method of Gomez and Gomez (1984).

\section{RESULTS AND DISCUSSION}

\section{Effect of wheat flour type on noodles quality:}

Different wheat flours (72\% extraction) under study, i.e. Sohag I, Giza 164, Hard Red winter and soft white were analysed for their moisture, protein, ash, fiber, lipids and total carbohydrates beside its pigment contents. The obtained results are shown in Table (1).

From the results presented in Table (1) it could be noticed that hard red winter wheat flour contained the highest percentage

Table (1): Chemical composition and pigment contents of wheat flour types used for noodles processing (on dry weight basis)

\begin{tabular}{|l|c|c|c|c|}
\hline \multicolumn{1}{|c|}{ Components \% } & \multicolumn{4}{|c|}{ Wheat flours (72\% extraction) } \\
\hline Total carbohydrates ( NFE) & $\begin{array}{c}\text { Hard flours } \\
\text { (Sohag 1) }\end{array}$ & $\begin{array}{c}\text { Soft flour } \\
\text { (Giza 164) }\end{array}$ & $\begin{array}{c}\text { Hard Red } \\
\text { Winter flour }\end{array}$ & $\begin{array}{c}\text { Soft white } \\
\text { flour }\end{array}$ \\
\hline Protein & 12.52 & 85.70 & 83.41 & 84.88 \\
\hline Ash & 0.74 & 11.58 & 13.85 & 12.50 \\
\hline Fiber & 0.53 & 0.60 & 0.55 & 0.54 \\
\hline Total lipids & 1.70 & 1.61 & 0.45 & 0.50 \\
\hline Moisture & 10.74 & 10.60 & 1.74 & 1.58 \\
\hline Pigment contents (ppm) & 3.76 & 2.53 & 4.39 & 12.25 \\
\hline
\end{tabular}

of protein while the lowest percentage was observed in Giza 164 variety. The highest content of total carbohydrates was observed in Sohag 1 and Giza 164, and the lowest contents of ash and fiber were observed in hard red winter and soft wheat white flours.

The same results also indicated that the Egyptian wheat flours (Sohag 1 and Giza 164) were higher in their lipid and crude fiber contents than those of American wheat flours (Hard red Winter and Soft White).

The results in the same Table showed also that hard red winter flour contained the highest amount of pigments, while the lowest amount was observed in Giza 164 flour.

The obtained results of chemical analysis of wheat flours under study were found to be in agreement with those of Mohamed (1992) and Shouk (1996).

The different wheat flours types under study were used for preparing instant fried noodles. The changes occurring in firmness, color and cooking quality properties (weight gain, volume gain and cooking loss) of noodles were determined and the obtained results are presented in Table (2).

From the results presented in Table (2) it could be observed that uncooked noodles made from hard red winter flour were higher in firmness and color values than those prepared from other types of the studied flours. This could be due to the high protein and pigment contents of hard red winter flour in comparison with other flours under study (Table 1). Miskelly (1984) reported that protein content was the most important factor affecting the color of noodles. Huang and Morrison (1988) and Shelke et al (1990) indicated that hard flour produced noodles with higher firmness than soft flour.

Fayoum J. Agric. Res. \& Dev., Vol.24, No.2, July, 2010 
Saad A. Hallabo; et al.

Table (2): Effect of flour type on firmness, color, and cooking quality properties of fried noodles

\begin{tabular}{|c|c|c|c|c|c|}
\hline \multirow[b]{2}{*}{$\begin{array}{c}\text { Type of flour ( } 72 \% \\
\text { extraction ) }\end{array}$} & \multirow[b]{2}{*}{$\begin{array}{c}* \text { Firmmess } \\
\mathrm{kg} / \mathrm{cm}^{2}\end{array}$} & \multirow[b]{2}{*}{$\begin{array}{l}* \text { Color } \\
\text { (A) }\end{array}$} & \multicolumn{3}{|c|}{ Cooking quality properties } \\
\hline & & & $\begin{array}{l}\text { Weight } \\
\text { gain \% }\end{array}$ & $\begin{array}{l}\text { Volume } \\
\text { gain \% }\end{array}$ & $\begin{array}{c}\text { Cooking } \\
\text { loss \% }\end{array}$ \\
\hline Hard Red Winter & 2.34 & 0.187 & 164 & 162.5 & 4.81 \\
\hline Soft White & 1.57 & 0.174 & 183 & 162.5 & 7.19 \\
\hline Sohag 1 & 1.76 & 0.181 & 187 & 162.5 & 5.41 \\
\hline Giza 164 & 1.51 & 0.151 & 165 & 157.5 & 8.88 \\
\hline
\end{tabular}

* Firmness and color of uncooked noodles.

From the results in the same Table it could be noticed that the noodles made from hard red winter flour had lower values for weight gain and cooking loss than those made from Sohag 1, Giza 164 and soft white by 14.02 and 12.50, 0.61 and $84.6 \%$, and 11.58 and $49.5 \%$, respectively. On the contrary, no remarkable changes in volume gain were found between noodles made from hard red winter and those made from Other flours under study. The difference in cooking quality properties between noodles samples could be attributed to its protein content, since samples with low protein were cooked more rapidly than those rich in protein and so as the protein content increased, the time required for the water to penetrate the protein network and gelatinize the starch granules increased (Jeffers $\boldsymbol{e t}$ al., 1979, and Oh $\boldsymbol{e t}$ al., 1985a). Beside, the same authors reported that during cooking of hard wheat noodles, the bond between surface starch and protein weakened in hot water, but the bond between surface protein and developed protein matrix stayed strong. This explained why noodles made from hard wheat flour has higher firmness values and lower cooking losses.

Liu et al., (2003) reported also that hardness of wheat is one of the factors which could be used as criteria for improving dry white Chinese noodle.

On the other hand, noodles prepared from the previous different flour types were also organoleptically evaluated for their sensory characteristics and the obtained results are shown in Table (3).

From the results presented in Table (3), it could be noticed that, no significant difference was found between the fried noodles samples made from Sohag 1, Giza 164 and Hard Red Winter (all 72\% extraction) for color, glossiness, speckleness, cooked starch, musty, hardness, chewiness, elasticity and overall acceptability.

From results in the same Table, it could be noticed that fried noodles samples made from soft white wheat flour had significantly lower values for almost all organoleptic properties in comparison with those made from other wheat flours under study.

Table (3): Effect of flour type on organoleptic properties of noodles.

\begin{tabular}{|l|c|c|c|c|c|}
\hline \multirow{2}{*}{\begin{tabular}{c}
\multirow{2}{*}{$\begin{array}{c}\text { Organoleptic } \\
\text { Properties }\end{array}$} \\
\cline { 2 - 5 }
\end{tabular}} & \multicolumn{3}{|c|}{ Wheat flour with 72\% extraction } & \\
\hline Color & $7.533^{\mathrm{A}}$ & $6.867^{\mathrm{A}}$ & $\begin{array}{c}\text { Hard Red } \\
\text { Winter }\end{array}$ & $\begin{array}{c}\text { Soft } \\
\text { White }\end{array}$ & L. S. D. \\
\hline Glossiness & $6.933^{\mathrm{A}}$ & $6.667^{\mathrm{A}}$ & $6.333^{\mathrm{AB}}$ & $5.600^{\mathrm{B}}$ & 0.896 \\
\hline Speekleness & $7.133^{\mathrm{A}}$ & $6.400^{\mathrm{AB}}$ & $7.000^{\mathrm{A}}$ & $5.600^{\mathrm{B}}$ & 1.136 \\
\hline Stickiness & $7.133^{\mathrm{A}}$ & $6.133^{\mathrm{A}}$ & $7.000^{\mathrm{A}}$ & $6.670^{\mathrm{A}}$ & 1.191 \\
\hline Cooked Starch & $7.333^{\mathrm{A}}$ & $7.000^{\mathrm{A}}$ & $7.667^{\mathrm{A}}$ & $7.133^{\mathrm{A}}$ & 1.886 \\
\hline Musty & $8.267^{\mathrm{A}}$ & $7.933^{\mathrm{A}}$ & $8.533^{\mathrm{A}}$ & $8.133^{\mathrm{A}}$ & 0.969 \\
\hline Hardness & $7.267^{\mathrm{A}}$ & $6.800^{\mathrm{AB}}$ & $7.400^{\mathrm{A}}$ & $6.333^{\mathrm{B}}$ & 0.740 \\
\hline Chewiness & $7.333^{\mathrm{A}}$ & $7.067^{\mathrm{A}}$ & $7.600^{\mathrm{A}}$ & $6.733^{\mathrm{A}}$ & 0.936 \\
\hline Elasticity & $7.133^{\mathrm{A}}$ & $6.467^{\mathrm{A}}$ & $7.333^{\mathrm{A}}$ & $6.867^{\mathrm{A}}$ & 1.025 \\
\hline Overall acceptability & $71.870^{\mathrm{A}}$ & $68.730^{\mathrm{A}}$ & $67.800^{\mathrm{A}}$ & $57.130^{\mathrm{B}}$ & 6.533 \\
\hline
\end{tabular}

Fayoum J. Agric. Res. \& Dev., Vol.24, No.2, July, 2010 
The mean scores with the same letters within the row are not significantly different at $5 \%$ level.

So, the Egyptian wheat flours (Sohag 1 and Giza 164) and American wheat flour (Hard red winter) could be used for production of instant fried noodles with acceptability higher than those made from soft white flour. Liu et al (2003) reported that hardness of wheat is one of the factors which could be used as criteria for improving dry white Chinese noodle.

2- Effect of flour extraction rate on noodles quality:

Chemical composition of wheat flour varities, i.e. Sohag 1 (hard flour) and Giza 164 (soft flour) with different extraction rates (72\% and 62\%) is shown in Table (4).

Table (4): Chemical composition and pigment content of wheat flour types with different extraction rates for noodles processing (on dry weight basis)

\begin{tabular}{|l|c|c|c|}
\hline \multirow{2}{*}{ Components \% } & \multicolumn{2}{|c|}{ Wheat flours } \\
\cline { 2 - 4 } & Hard flour (Sohag 1) & Soft flour (Giza 164) \\
\cline { 2 - 4 } & $62 \%$ & $62 \%$ \\
\hline Total carbohydrates ( NFE) & 85.42 & 86.23 \\
\hline Protein & 11.95 & & 11.26 \\
\hline Ash & 0.70 & 0.43 \\
\hline Fiber & 0.30 & 0.43 \\
\hline Total lipids & 1.63 & 1.65 \\
\hline Moisture & 10.36 & & 11.50 \\
\hline Pigments ( ppm ) & 3.34 & & 2.11 \\
\hline
\end{tabular}

The results presented in Tables ( 1 and 4) showed that total carbohydrates content was slightly increased as extraction rate decreased. On the other hand, protein, ash and fiber contents were found to decrease with decreasing the extraction rate. However, total lipids showed the same trend with Sohag 1 variety but with Giza 164 variety the lipids contents were approximately the same in both extraction rates. Slight decrease was also observed for pigments content with decreasing the extraction rate. Those differences in the chemical composition might be due to the bran layer contamination which increased as extraction rate of flour increased. Similar findindings were reported by Kruger et al (1994) and Shouk (1996).

The changes occurring in firmness, color and cooking quality properties of fried noodles prepared from the Egyptian wheat flours (Sohag 1 and Giza 164) with extraction rates of $62 \%$ and $72 \%$ were studied and the obtained results are shown in Table (5).

From these results presented in Tables ( 2 and 5) it could be noticed that firmness and color values of uncooked noodles made from Sohag 1 ( $72 \%$ extraction) were higher by about 3.41 and $20.4 \%$ than those made from Sohag 1 of $62 \%$ extraction. This could be due to that Sohag 1 wheat flour with $72 \%$ extraction contained higher level of protein and pigments content than $62 \%$ extraction flour (Table 4).

Table (5): Effect of flour extraction rate on the firmness, color, and cooking quality properties of fried noodles

\begin{tabular}{|l|c|c|c|c|c|}
\hline \multirow{2}{*}{$\begin{array}{c}\text { Extraction rate of } \\
\text { flour }\end{array}$} & $*$ Firmness & $*$ Color (A) & \multicolumn{3}{|c|}{ Cooking quality properties } \\
\cline { 2 - 6 } & $\mathbf{k g / \mathbf { c m } ^ { 2 }}$ & & $\begin{array}{c}\text { Weight } \\
\text { gain \% }\end{array}$ & $\begin{array}{c}\text { Volume } \\
\text { gain \% }\end{array}$ & $\begin{array}{c}\text { Cooking } \\
\text { loss \% }\end{array}$ \\
\hline Sohag 1 & & & & & \\
\hline 62\% extraction & 1.70 & 0.144 & 194 & 172.0 & 6.52 \\
\hline Giza 164 & & & & & \\
\hline 62\% extraction & 1.36 & 0.145 & 176 & 162 & 9.79 \\
\hline
\end{tabular}

* Firmness and color of uncooked noodles.

Fayoum J. Agric. Res. \& Dev., Vol.24, No.2, July, 2010 
The same trend was also observed with noodles prepared from Giza 164. The firmness and color values of uncooked noodles made from Giza 164 (72\% extraction) were higher than those of uncooked noodles that are made from Giza 164 with extraction rate of $62 \%$ by 11.53 and $7.64 \%$, respectively.

Concerning the changes occurring in the cooking quality properties of fried noodles prepared from wheat flours of different extraction rates, results presented in Table (5) showed that weight gain, volume gain and cooking loss values were 194 and $176 \%, 172$ and 162, 6.52 and 9.79\% for noodles prepared from Sohag 1 and Giza 164 with $62 \%$ extraction rate, respectively, in comparison with 187 and $165 \%, 162.5$ and $157.5 \%$ and 5.41 and $8.88 \%$ for the same parameters of wheat flour with $72 \%$ extraction rate, respectively.

From the above results, it could be noticed that fried noodles made from Sohag 1 wheat flour with extraction rate of $62 \%$ showed slightly higher in weight gain, volume gain and cooking loss than those made from Sohag 1 wheat flour with extraction rate of $72 \%$. The same trend was also observed with noodles prepared from Giza 164 wheat flour of extraction rate of $62 \%$ and $72 \%$. From these results, it could be concluded that as the extraction rate increased from $62 \%$ to $72 \%$, the weight gain, volume gain and cooking loss decrease. These results could be related to the high protein content in the flour of $72 \%$ extraction in comparison with the flour of $62 \%$ extraction (Table, 4), which resulted in less penetration rate for water, so little starch swelling occurred. These results agreed also with those obtained by Moss $\boldsymbol{e t}$ al. (1987) and Gu-Sik and Sung-Kom (1991) who mentioned that the starch in the low protein sample was more swollen and the weight and volume of cooked noodles decreased as the protein content of flour increased.

Moreover, the fried noodles prepared from the previous different extraction rate of Egyptian wheat flours were also organoleptically evaluated for their sensory characteristics and the obtained results are statistically analyzed and shown in Table (6).

Table (6): Effect of extraction rate of flour on organoleptic properties of noodles

\begin{tabular}{|l|c|c|c|}
\hline \multirow{2}{*}{ Organoleptic properties } & \multicolumn{3}{|c|}{ Wheat flour with 62\% extraction } \\
\cline { 2 - 4 } & $\begin{array}{c}\text { Sohag 1 } \\
\text { 62\% extrn. }\end{array}$ & $\begin{array}{c}\text { Giza 164 } \\
\mathbf{6 2 \%} \text { extrn. }\end{array}$ & $\begin{array}{c}\text { L.S.D. } \\
\text { (5\%) }\end{array}$ \\
\hline Color & $6.467^{\mathrm{AB}}$ & $6.333^{\mathrm{AB}}$ & 0.722 \\
\hline Glossiness & $6.067^{\mathrm{A}}$ & $6.667^{\mathrm{A}}$ & 1.009 \\
\hline Speekleness & $6.133^{\mathrm{A}}$ & $6.400^{\mathrm{A}}$ & 1.028 \\
\hline Stickiness & $5.667^{\mathrm{B}}$ & $6.133^{\mathrm{AB}}$ & 1.046 \\
\hline Cooked starch & $6.800^{\mathrm{A}}$ & $7.000^{\mathrm{A}}$ & 1.041 \\
\hline Musty & $7.330^{\mathrm{B}}$ & $7.933^{\mathrm{A}}$ & 1.044 \\
\hline Hardness & $6.933^{\mathrm{A}}$ & $7.067^{\mathrm{A}}$ & 0.895 \\
\hline Chewiness & $6.333^{\mathrm{A}}$ & $6.467^{\mathrm{A}}$ & 1.962 \\
\hline Elasticity & $7.067^{\mathrm{A}}$ & $6.800^{\mathrm{A}}$ & 1.036 \\
\hline Overall acceptability & $65.870^{\mathrm{A}}$ & $68.730^{\mathrm{A}}$ & 6.261 \\
\hline
\end{tabular}

The mean scores with the same letters within the row are not significantly different at $5 \%$ level.

From the results presented in Tables (3 and 6), it could be observed that no significant differences were found between noodles samples made from the previous different extraction rate of Sohag 1 or Giza 164 wheat flour, for glossiness, speckleness, cooked starch, hardness, chewiness, elasticity and overall acceptability.

Fayoum J. Agric. Res. \& Dev., Vol.24, No.2, July, 2010 
On the other hand, noodles samples made from Sohag 1 wheat flour with extraction rate of $72 \%$ had significant differences for musty comparison with those made from the previous extraction rate of wheat flour under study.

These results indicated that extraction rate of flour had no effect on the organoleptic properties of fried noodles. Also, it could be noticed that noodles made from Sohag 1 wheat flour with $72 \%$ extraction had higher scores for all the organoleptic properties.

\section{3- Effect of particle size of wheat flour on noodles quality:}

The chemical composition of fractions (1) and (2) and the parent flour (72\% extraction) are shown in Table (7).

Table (7): Chemical composition and pigment content of wheat flour $\mathbf{7 2 \%}$ extraction and their fractions (on dry weight basis).

\begin{tabular}{|l|c|c|c|}
\hline $\begin{array}{c}\text { Components } \\
\text { \% }\end{array}$ & $\begin{array}{c}\text { Wheat flour } \\
\text { extraction (72\%) }\end{array}$ & $\begin{array}{c}\text { Flour fraction } \\
\text { (coarse) }\end{array}$ & $\begin{array}{c}\text { Flour fraction }^{(\mathbf{2})} \\
\text { (fine) }\end{array}$ \\
\hline Total carbohydrates & 84.52 & 84.74 & 84.10 \\
\hline Protein & 12.50 & 12.75 & 13.61 \\
\hline Ash & 0.74 & 0.51 & 0.43 \\
\hline Fiber & 0.53 & 0.30 & 0.17 \\
\hline Total lipids & 1.70 & 1.70 & 1.69 \\
\hline Moisture & 10.74 & 11.12 & 11.26 \\
\hline Pigment content (ppm) & 3.76 & 2.79 & 2.41 \\
\hline
\end{tabular}

Fraction 1 (coarse particle size):represents $38 \%$ from the original flour and have particle size less than $0.250 \mathrm{~mm}$ and more than $0.125 \mathrm{~mm}$.

Fraction 2 (fine particle size): represents $24 \%$ from the original flour and have particle size less than $0.125 \mathrm{~mm}$ and more than $0.063 \mathrm{~mm}$.

From the results presented in Table (7) it could be noticed that the contents varied according to the particle size of flour. The protein content increased, while ash and fiber in addition to pigment contents decreased as particle size of the flour decreased. However, total carbohydrates and total lipids contents appeared to be not affected by fractionation process. Similar findings were reported by Faheid (1992) and Raouf et al. (1992).

The changes occurring in the firmness, color, and cooking quality properties of fried noodles prepared from Sohag 1 wheat flour with $72 \%$ extraction and their fractions were determined and the results are shown in Table (8).

Table (8): Effect of flour fractionation on the firmness, color, and cooking quality properties of instant fried noodles.

\begin{tabular}{|l|c|c|c|c|c|}
\hline \multirow{2}{*}{ Type of flour } & \multirow{2}{*}{$\begin{array}{c}\text { Firmness* } \\
\text { kg/cm }\end{array}$} & \multirow{2}{*}{$\begin{array}{c}\text { Color* } \\
\text { (A) }\end{array}$} & & \multicolumn{3}{|c|}{$\begin{array}{c}\text { Cookight } \\
\text { gain \% }\end{array}$} & $\begin{array}{c}\text { Volume } \\
\text { gain\% }\end{array}$ & $\begin{array}{c}\text { Cooking } \\
\text { loss\% }\end{array}$ \\
\hline Parent flour & 1.76 & 0.181 & 187 & 162 & 5.41 \\
\hline Fraction 1 & 1.85 & 0.177 & 200 & 175 & 6.32 \\
\hline Fraction 2 & 1.93 & 0.170 & 180 & 175 & 5.96 \\
\hline
\end{tabular}

* Firmness and color of uncooked noodles.

From these results it could be noticed that firmness values of produced uncooked instant fried noodles increased with decreasing particle size of the flour. The highest firmness values were observed in the noodles made from fraction $2(0.125-0.063 \mathrm{~mm})$. This is mainly due to the higher protein content in flour with fine particle size. These results are in agreement with those reported by Oh $\boldsymbol{e t ~ a l . ~ ( 1 9 8 5 b ) ~ w h o ~ s t a t e d ~ t h a t ~ f l o u r ~}$

Fayoum J. Agric. Res. \& Dev., Vol.24, No.2, July, 2010 
with high starch damage and small particle size gave increasing in firmness of uncooked noodles. Also, they observed that the flour protein may produce a tight noodles structure resulting from a strong adherence between starch and protein.

From the same results (Table 8) it could be also observed that the color value of noodles made from parent flour (72\% extraction) was higher than that of noodles made from fraction (1) or fraction (2). These results could be attributed to the pigment content and bran contamination in the parent flour in comparison with fraction (1) or fraction (2). These results confirmed those of Oh et al. (1985b) and Kruger et al. (1994).

The noodles cooking quality properties (weight gain, volume gain and cooking loss) were also found to be affected by flour fractionation. The results indicated that noodles made from fraction (1) showed considerably higher weight gain, volume gain cooking loss than those made from the parent flour, while that made from fraction (2) showed high cooking loss and volume gain and slightly low weight gain comparing with those made parent flour. These results were explained by Moss et al. (1987). They reported that for optimum gluten development in the noodle dough, the flour particle size should be relatively fine, but below $180 \mu \mathrm{m}$, particle size become not critical. They also found that the protein structure in the fine samples was more uniform than the coarse samples and the very poor eating quality and large cooking loss of coarser samples would mainly due to damage starch, rather than the slightly impaired protein development. Their results indicated also that noodles made from flour of particle size of 85-180 um had lower cooking loss than that prepared from flour with particle size of $265-355 \mu \mathrm{m}$.

On the other hand, noodles prepared from the previous Sohag 1 wheat flour ( $72 \%$ extraction) and their fractions ( 1 and 2 ) were also organoleptically evaluated and the obtained results are subjected to the statistical analysis and the obtained data are shown in Table (9).

Table (9): Effect of flour fractionation on organoleptic properties of instant fried noodles.

\begin{tabular}{|l|c|c|c|c|}
\hline \multirow{2}{*}{\begin{tabular}{c}
\multirow{2}{*}{$\begin{array}{c}\text { Organoleptic } \\
\text { Properties }\end{array}$} \\
\cline { 2 - 4 }
\end{tabular}} & $\begin{array}{c}\text { Parent flour } \\
\mathbf{7 2 \%} \text { extraction) }\end{array}$ & $\begin{array}{c}\text { Flour } \\
\text { fraction (1) }\end{array}$ & $\begin{array}{c}\text { Flour fraction } \\
\text { (2) }\end{array}$ & $\begin{array}{c}\text { L.S.D } \\
\text { at 5\% level }\end{array}$ \\
\hline Color & $7.750^{\mathrm{A}}$ & $8.188^{\mathrm{A}}$ & $6.313^{\mathrm{B}}$ & 1.193 \\
\hline Glossiness & $6.625^{\mathrm{A}}$ & $7.688^{\mathrm{A}}$ & $6.688^{\mathrm{A}}$ & 1.054 \\
\hline Speekleness & $6.688^{\mathrm{A}}$ & $7.563^{\mathrm{A}}$ & $6.750^{\mathrm{A}}$ & 0.852 \\
\hline Stickiness & $5.625^{\mathrm{B}}$ & $7.313^{\mathrm{A}}$ & $6.250^{\mathrm{AB}}$ & 1.344 \\
\hline Cooked starch & $7.188^{\mathrm{A}}$ & $7.438^{\mathrm{A}}$ & $7.000^{\mathrm{A}}$ & 1.145 \\
\hline Musty & $8.250^{\mathrm{A}}$ & $8.438^{\mathrm{A}}$ & $8.250^{\mathrm{A}}$ & 0.822 \\
\hline Hardness & $6.875^{\mathrm{AB}}$ & $7.938^{\mathrm{A}}$ & $6.438^{\mathrm{B}}$ & 1.208 \\
\hline Chewiness & $6.938^{\mathrm{AB}}$ & $7.875^{\mathrm{A}}$ & $6.813^{\mathrm{B}}$ & 0.956 \\
\hline Elasticity & $7.500^{\mathrm{A}}$ & $7.813^{\mathrm{A}}$ & $6.188^{\mathrm{B}}$ & 1.227 \\
\hline Overall acceptability & $62.940^{\mathrm{A}}$ & $66.130^{\mathrm{A}}$ & $60.130^{\mathrm{A}}$ & 63.46 \\
\hline
\end{tabular}

The mean scores with the same letters within the row are not significantly different at $5 \%$ level.

From the results presented in Table (9) it could be noticed that no significant difference was found between samples made from parent flour (72\% extraction) and their fraction (1) or (2) for glossiness, speckleness, cooked starch, musty and overall acceptability.

From the same Table, it could be observed that there were significant differences between samples made from the parent flour (72\% extraction) and fraction (2) for color and elasticity. This may be due to finely hard wheat flour, when cooked gave weak

Fayoum J. Agric. Res. \& Dev., Vol.24, No.2, July, 2010 
noodles because of their high level of damage starch which caused higher swelling and softening in the cooked noodles (Oh et al., 1985c). How ever the parent flour was found to be significantly different from fraction (1) for only stickiness.

From all the previous results it could be reveald that wheat flour type (hard or soft), flour extraction rate and particle size are important factors affecting noodles quality. Hussein, et al., (2010) reported that the differences that usually occur in the wheat flour products depend on the wheat variety (hard or soft wheat) rate of flour milling and particle size.

However, from the obtained results it could be concluded that best instant fried noodles can be produced using hard flour with extraction rate of $72 \%$ and medium particle size $(0.125-0.250)$.

\section{REFERENCES}

AOAC (2005): Official Methods of Analysis of AOAC International. $18^{\text {th }}$ edition. Published by AOAC International. Gaitherslourg, Marland, U.S.A.

Code of Federal Regulations (1981): Part 139. Office the Federal Register, Washington, D.C. Title 21- Food and Drugs.

Fahied, S.M.M. (1992): Application of sieve fractionation on wheat flours to improve different quality characteristics for bread making. Egypt J. Food Sci., 20(1): 159-173.

Fen, G. and Seib, P.A. (1994): Instrumental probe and method to measure stickiness of cooked Spaghetti and noodles. Cereal Chem. 71 (4) 330-337.

Galvez, F.F. and Resurreccion, A.V. (1990): Comparison of three descriptive analysis scaling methods for the sensory evaluation of noodles. J. of Sensory Studies. 5: 251-263.

Gomez, K.A. and Gomez, A.A. (1984): Stastistical procedures for Agricultural Research. 2Ed. Chap. 3, PP. 84-129. John wily and Sons Editor Fnc, U.S.A.

Gu-Sik, C. and Sung-Kon, K. (1991): Effects of wheat flour protein contents on Raymon (deep - fried instant noodle) quality. Korean J. Food Sci. Technology, 23 (6): 649-655.

Habib, A.T. and Brown, H.D. (1956): Factors influencing the color of potato chips. Food Technology, March 12, 332-336.

Huang, S. and Morrison, W.R. (1988): Aspects of protein in Chinese and British coman (hexapolid) wheat related to quality of white and yellow Chinese noodle. J. of Cereal Science, 18: 177-187.

Hussein, A.M.S.; Kamil, M.M.; and Ragab, G.H. (2010). Technological properties of some Egyptian new wheat varities. Journal of American Science. 6(10): 1160-1171.

Jeffers, H.C.; Noguchi, G. and Rubenthialerm, G.L. (1979): Effect of legume fortifiers on the quality of udon noodles. Cereal Chem. 56 (6): 573-576.

Kim, S.K. (1996): Instant noodle technology. Cereal Foods World. April. 41(4): 214217.

Kruger, J.E.; Anderson, M.H. and Dexter, J.E. (1994): Effect of flour refinement on raw Cantonese noodle color and texture. Cereal Chem., 71(2): 177-182.

Liu, J.J.; He, Z.H., Zhao, Z.D.; Pena, R.J. and Rajaram, S. (2003). Wheat quality traits and quality parameters of cooked dry white Chinese noodles. Euphytica 131:147-154.

Miskelly, D.M. (1984): Flour component affecting pasta and noodle color. J. Sci. Food Agric., 35: 363-471.

Miskely, D.M. (1993): Noodles-a new look at an old food. Food Australia 45 (10), October, 495-500.

Fayoum J. Agric. Res. \& Dev., Vol.24, No.2, July, 2010 
Mohamed, E.A. (1992): Effect of different flours and their blends on bread quality. $\mathrm{Ph}$. D. Thesis, Fac. Agric, Cairo Univ.

Moss. R.P.; Gore, J. and Murray, I.C. (1987): The influence of ingredients and processing variables on the quality and microstructure of Hokkien, Cantonese and instant noodles. Food Microstructure, 6: 63-74.

Oh, N.H.; Seib, P.A. and Ward, A.B. (1985a). Noodles. II. The surface firmness of cooked noodles from soft and hard wheat flours. Cereal Chem. 62 (6): 431-436.

Oh, N.H.; Seib, P.A. and Ward, A.B. (1985b): Noodles. IV. Influence of flour protein, extraction rate, particle size and starch damage on the quality characteristics of dry noodles. Cereal Chem. 62 (6): 441-446.

Oh, N.H.; Seib, P.A.; Ward, A.B. and Deyoe, C.W. (1985): Noodles VI. Functional properties of wheat flour components in oriental dry noodles. Cereal Foods World, 30 (2): 176-178.

Raouf, M.S.; Badei, A.Z.M. and Wasfy, A.S.M. (1992): Sieve fractionated wheat flours. I. Chemical composition of fractions and rheology dough. Egypt. J. Food Sci., (20): 75-84.

Rho, K.L.; Chung, O.K. and Chung, D.S. (1986): Retardation of rancidity in deepfried noodles (Ramyon). J.A.O.C.S. 63 (2): 251-256.

Shelke, K.; Dick, J.W.; Holm, Y.F. and Look, S. (1990): Chinese wet noodle formulation: A response surface methodology study. Cereal Chem. 67(4): 336342.

Shouk, A.A.L. (1996): Production and evaluation of whole meal wheat bread. Ph. D. Thesis Dep. Food Sci. \& Tech. Fac. of Agric, Cairo Univ.

Walash, D.E. and Gilles, K.A. (1971): The influence of protein composition on spaghetti quality. Cereal Chem. 48 (4): 544-554.

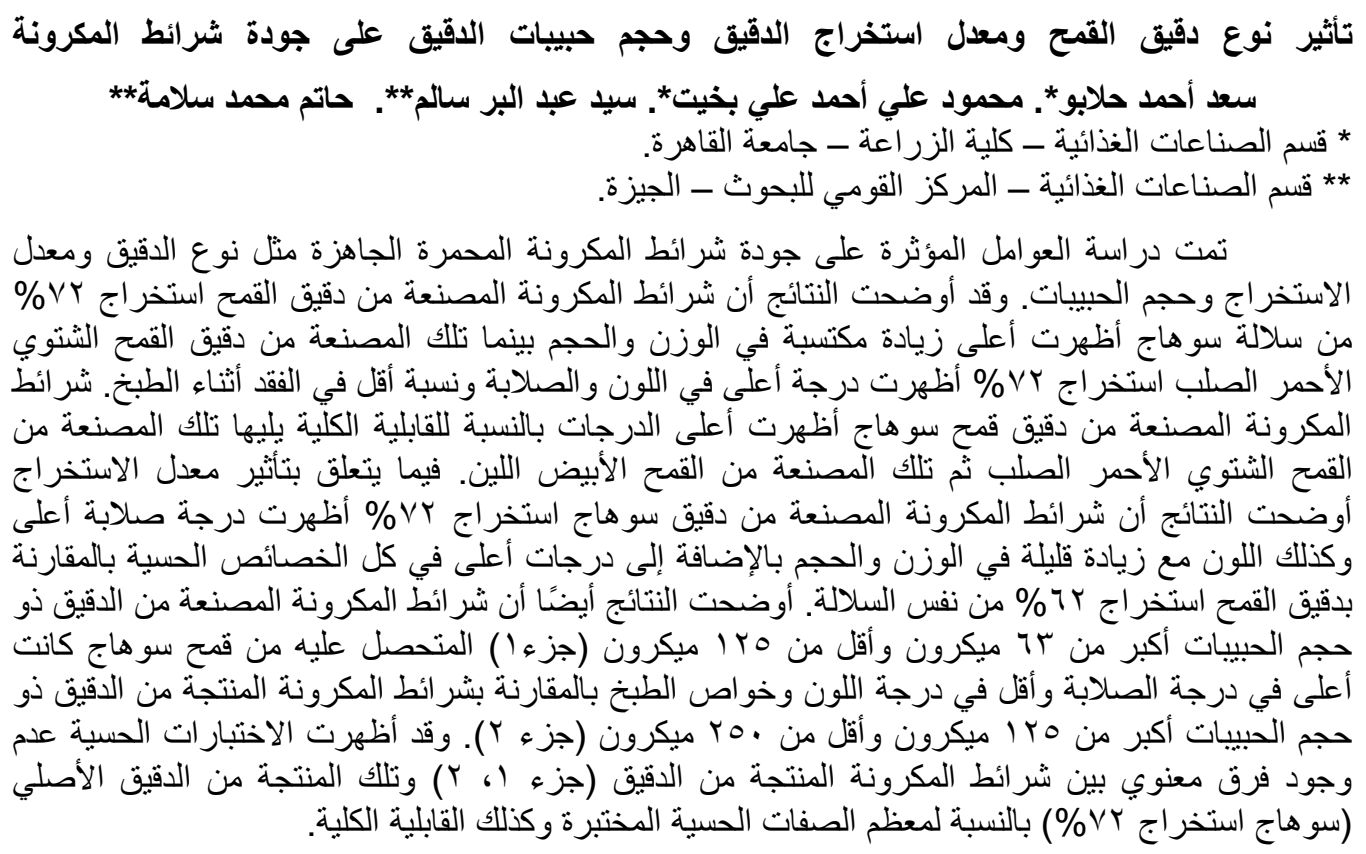

Fayoum J. Agric. Res. \& Dev., Vol.24, No.2, July, 2010 